American Journal of Environmental Sciences 6 (1): 33-40, 2010

ISSN 1553-345X

(C) 2010 Science Publications

\title{
Arsenic and Antimony Content in Soil and Plants from Baia Mare Area, Romania
}

\author{
${ }^{1}$ Gabriela Oprea, ${ }^{2}$ Angela Michnea, ${ }^{1}$ Cristina Mihali, ${ }^{3}$ Marin Şenilă, \\ ${ }^{3}$ Cecilia Roman, ${ }^{1}$ Stela Jelea, ${ }^{1}$ Claudia Butean and ${ }^{4}$ Cristian Barz \\ ${ }^{1}$ Department of Chemistry-Biology, Faculty of Sciences, North University of Baia Mare, \\ 76 Victoriei Street, 430122 Baia Mare, Romania \\ ${ }^{2}$ Department of Monitoring, Environmental Protection Agency Maramureş, 1A Iza Street, \\ 430073 Baia Mare, Romania \\ ${ }^{3}$ Environmental Analysis Laboratory, National Research and Development Institute for Optoelectronics, \\ Research Institute for Analytical Instrumentation, 67 Donath Street, 400293 Cluj-Napoca, Romania \\ ${ }^{4}$ Department of Electrical Engineering, Faculty of Engineering, North University of Baia Mare, \\ 62A Dr. V. Babes Street, 430083 Baia Mare, Romania
}

\begin{abstract}
Problem statement: The objective of this research was to evaluate the degree of soil contamination with arsenic and antimony in Baia Mare, a nonferrous mining and metallurgical center located in the North West region of Romania. The soil in the area is affected by the emissions of powders containing metals from metallurgical factories. Previous studies indicated the soil contamination with copper, zinc, cadmium and lead, but there is few data about the actual level of soil pollution with arsenic and antimony. Approach: The soil samples were collected from 2 districts of Baia Mare: Ferneziu, which is located in the proximity of a lead smelter and Săsar district which is located along the Săsar River in the preferential direction of the wind over a metallurgical factory producing lead. As reference was considered Dura area located in a less polluted hilly area, in the west part of the town. Samples of soil and plants from the residential area of Ferneziu, Săsar and Dura districts were collected. The arsenic determination was carried out by inductively coupled plasma atomic emission spectrometry and the antimony determination by inductively coupled plasma mass spectrometry. Results: In Ferneziu area, the concentration of arsenic in soil ranged between 0.25 and $255 \mathrm{mg} \mathrm{kg}^{-1}$. In Săsar district the arsenic concentration in the soil ranged between 5.5 and $295 \mathrm{mg} \mathrm{kg}^{-1}$. Regarding antimony, in Ferneziu area the concentration ranged between 5.3 and $40.6 \mathrm{mg} \mathrm{kg}^{-1}$; while in Săsar, antimony soils concentrations vary in the range: 0.9-18.4. Arsenic and antimony concentrations in plants were low for almost of the samples, both in Ferneziu and Săsar area indicating a low mobility of these elements in the studied soils. Conclusion: This study indicated the soil pollution with arsenic both in Ferneziu district and in Săsar district. The soil pollution with antimony was found especially in Ferneziu district.
\end{abstract}

Key words: Arsenic, antimony, soil, plant, polluted areas, statistic interpretation

\section{INTRODUCTION}

More and more studies have been lately published about the geochemical characterization of the soil and subsoil and about the differentiation of the additional contribution of metals and metalloids due to the ongoing human activities.

In this context, there is available data concerning the nonferrous metals content in soil and plants in the Baia Mare area which is significant for mining and metallurgical activities (Frentiu et al., 2008; 2009;
Cordos et al., 2007; Damian et al., 2008), but only fewer works have investigated the Arsenic (As) presence and there is no paper referring to the content of antimony $(\mathrm{Sb})$ in the soil in this area.

The researches conducted in Baia Mare area have highlighted multiple pollution by heavy metals $(\mathrm{Pb}, \mathrm{Cd}$, $\mathrm{Zn}, \mathrm{Cu})$ in the residential, agricultural and forestry soils felt at a distance over $25-30 \mathrm{~km}$ around the major pollution sources, as a consequence of the high emission levels and high frequency of exceeding the maximum admissible concentrations of $\mathrm{Pb}$ and $\mathrm{Cd}$ in

Corresponding Author: Gabriela Oprea, Department of Chemistry-Biology, Faculty of Sciences,

North University of Baia Mare, No 76, Victoriei Road, 430122, Baia Mare, Romania 
the ambient air. Air pollution and dust deposition are favored by the local weather conditions resulting from the geographical position and topography of the area. The atmospheric calm and generally low wind speed $\left(<2.5 \mathrm{~m} \mathrm{sec}^{-1}\right)$ characteristic for a period of approximately six months in the cold period of the year lead to a very poor ventilation of the area and to a very low capacity of dispersion of pollutants in the atmosphere.

The activities connected to the non-ferrous metallurgy are, due to their emissions in the air, important sources of soil pollution. Heavy metal pollution around metallurgical plants is often accompanied by pollution with As and $\mathrm{Sb}$ considering the fact that usually these elements accompany nonferrous minerals (Nakamaru et al., 2006; Tighe et al., 2005). Generally, the pollution sources with As and Sb are represented by the metallurgical plants, ore preparation plants and the use of organic fertilizers.

The terrestrial abundance of arsenic is about 1.5$3 \mathrm{mg} \mathrm{kg}$ and it is derived from natural and anthropogenic sources. Arsenic is a metalloid that occurs naturally, being the 20th in terms of abundance in the earth's crust. Arsenic and its compounds present environmental mobility. Natural oxidation of rocks transforms the arsenic sulfides in arsenic trioxide, which enters in the arsenic cycle in the form of powder or dissolved in rainwater, rivers or groundwater. Arsenic may enter in the food chain through plants or animals (Mandal and Suzuki, 2002).

Antimony is present in polluted soils mainly in immobile form. In contrast, in the areas with high mobile antimony a considerable accumulation in some plant is observed, especially in the leaves of spinach, but there are very few data on antimony accumulation in plants (De Gregori et al., 2004). The abundance of antimony in the earth's crust is $0.2 \mathrm{mg} \mathrm{kg}^{-1}$ and the background concentrations in soils are in the range of 0.3-8.4 $\mathrm{mg} \mathrm{kg}^{-1}$ (He, 2007).

The biogeochemical behavior of antimony is less studied, but there is some evidence showing that it is similar to arsenic with which it is often associated in nonferrous ores. Both elements exist in either oxidation state +3 or +5 , the latter being widespread in oxidizing conditions. The labile concentrations of $\mathrm{Sb}$ and $\mathrm{As}$ in soils are probably controlled by adsorptionprecipitation reactions with the oxides from the clay surface and with the $\mathrm{Fe}, \mathrm{Al}$ or $\mathrm{Mn}$ oxyhydroxides (Casado et al., 2007).

The mineral assemblages from Baia Mare area include native elements ( $\mathrm{Au}, \mathrm{Ag}, \mathrm{Cu}, \mathrm{As}, \mathrm{S})$, sulphide minerals (pyrite, chalcopyrite, arsenopyrite, sphalerite, galena, stibnite) sulphosalts (tetrahedrite, jamesonite, semseyite, pyrargyrite) and tungstates (wolframite, scheelite), together with quartz, clay minerals, adularia, carbonates, rhodonite and barite as gangue minerals (Grancea et al., 2002).

Baia Mare was and still is a hot spot on the map of soil pollution with non-ferrous metals such as $\mathrm{Pb}, \mathrm{Cu}$, $\mathrm{Cd}$, and $\mathrm{Zn}$. The main sources of soil pollution have been and still are the particle emissions from metallurgical plants in the city, which besides the heavy metals listed above contain also As and $\mathrm{Sb}$.

As regards the origin of arsenic species it is known that the non-Ferrous ores in the area contain ArsenicSulfides (FeAsS), which are processed by frying forming the volatile $\mathrm{As}_{2} \mathrm{O}_{3}$ that can be oxidized to $\mathrm{FeAsO}_{4}$ and exhausted with ash particles. The particulate matter emitted is falling not only in the vicinity of plants but also in other areas in the city (Cordos et al., 2006).

Currently, the metallurgical industry has considerably reduced its activity by closing or reducing its production capacity. However, Baia Mare has to face the historical soil pollution.

In the areas of industrial impact in Baia Mare, the soil contains between 10 and $1725 \mathrm{mg} \mathrm{kg}^{-1} \mathrm{As}$, of which over $90 \%$ is inorganic As (V) (Frentiu et al., 2009). Similar results have been obtained by determining As in a network of 35 sampling points in the city of Baia Mare, on samples from $20 \mathrm{~cm}$ depth where the concentration of As ranged between 22.6 and $1910 \mathrm{mg} \mathrm{kg}^{-1}$ (Miclean et al., 2008). Large amounts of non-ferrous metals in the soil, including the significant presence of As may indicate a severe situation that requires urgent actions in order to reduce the pollution and remediate the contaminated sites. These data should be connected with the possible presence of these metals in plants, which favors their uptake.

\section{MATERIALS AND METHODS}

Location of the studied area: The soil and plant samples had been collected from 2 zones of the Baia Mare municipality (Ferneziu district and Săsar district), where, as shown in previous studies, higher concentrations of heavy metals have been found in the soil, as a consequence of the falling dust containing metals from direct, diffuse or fugitive emissions from the metallurgical plants from the area (Damian et al., 2008). For the comparative analysis of the data, also a reference zone had been selected (Dura area). The zones of interest for the present study have been marked on the map in Fig. 1. 
Am. J. Environ. Sci., 6 (1): 33-40, 2010

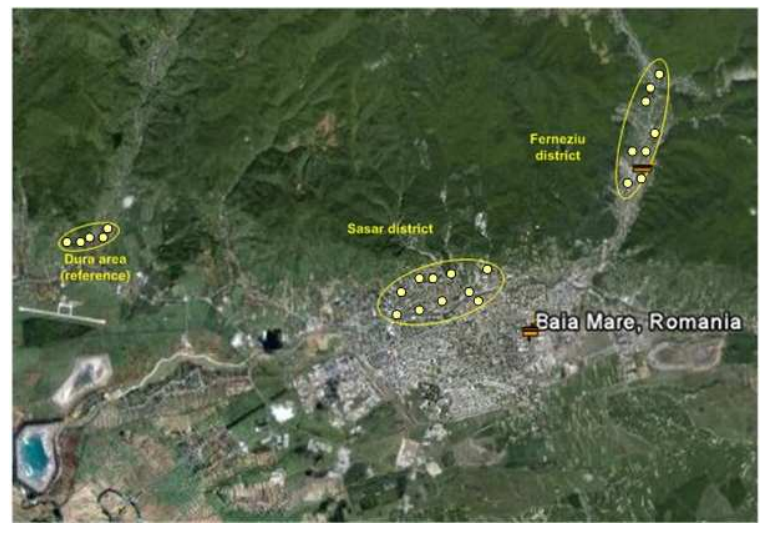

Fig. 1: Map of the studied areas

Soil and plant sampling: The soil samples had been taken during July-August 2009 from a depth of 0$10 \mathrm{~cm}$ and each soil sample was accompanied by a sample of the plants growing on it. The soil samples were collected from several locations representing garden soils, residential area soils and industrial area soils. The plant samples from the garden soils were vegetables used in human alimentation as onion (Allium cepa) and dill (Anethum graveolens); while for the other locations the plant samples had been collected from the spontaneous flora (Agrostis, Agropirum, Trifolium repens, Urtica dioica). The samples were conditioned and prepared in laboratory for the determination of $\mathrm{pH}$ in the aqueous extract of the soil and of the As and $\mathrm{Sb}$ content. The locations for sampling have been chosen in each studied zone by drawing an imaginary area of $1 \mathrm{~m}^{2}$ on whose diagonal 3 samples of approximately $0.5 \mathrm{~kg}$ have been extracted from a depth between $0-10 \mathrm{~cm}$, out of which through mixing and homogenization the representative sample had been obtained. In the same time, there had been collected aerial parts of the plants growing in the locations from where the soil samples had been drawn, with the exception of the onion whose bulb had been also collected.

Samples preparation: The soil samples were crushed and dried at room temperature for $48 \mathrm{~h}$, then passed through a $2 \mathrm{~mm}$ sieve. Thus from the processed sample a sub-sample of $100 \mathrm{~g}$ was obtained through the method of quarters, which was at its turn milled and passed through a sieve of 100 microns. From this sub-sample 2 $\mathrm{g}$ of soil were taken and subjected to mineralization with aqua regia according to ISO 11466: 1999. The plant samples were intensely rinsed with tap water and deionized water and were dried in oven at a temperature of max. $40^{\circ} \mathrm{C}$, broken up, homogenized, passed through a $0.1 \mathrm{~mm}$ sieve. All the soil and plant samples had been kept in sealed and carefully labeled plastic bags. The plant samples were digested in aqua regia following the method from ISO 11466: 1999. A quantity of $1 \mathrm{~g}$ soil sample was subjected to extraction with aqua regia and hydrogen peroxide. The content of As and $\mathrm{Sb}$ in the obtained extracts was determined by spectrometric methods.

Samples analysis: The $\mathrm{pH}$ measurement of the aqueous suspension 1:5 (w/v) of the $<2 \mathrm{~mm}$ fraction of the soil samples was performed. The $\mathrm{pH}$ was measured with Consort $2000 \mathrm{pH}$-meter equipped with a combined $\mathrm{pH}$ electrode. The distilled water used for the preparation of the suspension had been previously boiled and cooled. The determination of As was made using the inductively coupled plasma atomic emission spectrometer, ICP-AES, with simultaneous detection Optima 5300 DV (Perkin Elmer), with axial and radial dual vision, while for the determination of Sb the ELAN DRC II (Perkin Elmer) inductively coupled plasma atomic emission spectrometer, ICP-AES was used.

The reagents used during the process were of analytical grade: Concentrated nitric acid, concentrated hydrochloric acid and 30\% hydrogen peroxide from Merck (Germany). For the dilution ultra pure water obtained through a Direct Q3 Millipore system was used. The calibration was made using monoelement As and $\mathrm{Sb}$ standards of $1000 \mu \mathrm{g} \mathrm{mL}^{-1}$ (Merck, Germany). The calibration solutions were prepared by dilutions with $2 \% \mathrm{HNO}_{3}(\mathrm{v} / \mathrm{v})$.

\section{RESULTS}

The $\mathrm{As}$ and $\mathrm{Sb}$ average contents and their variation range in the soil and plant samples are presented in Table 1. The average content of As in the soil of Ferneziu district, in the close vicinity of the metallurgical plant that produces primary lead was $53 \mathrm{mg} \mathrm{kg}^{-1}$. In the residential area from the central and north-west part of the city (Săsar district) the average content of As in the soil samples was almost double, respectively $102 \mathrm{mg} \mathrm{kg}^{-1}$. As compared to the values admitted by the current legislation of Romania, in Ferneziu district $50 \%$ of the samples had a higher content than the alert threshold $\left(15 \mathrm{mg} \mathrm{kg}^{-1}\right)$ and $25 \%$ of the samples had a content that exceeded the intervention threshold $\left(25 \mathrm{mg} \mathrm{kg}^{-1}\right)$ and in Săsar district the content of $70 \%$ of the samples exceeded the alert threshold and the content of $60 \%$ of samples was above the intervention threshold. In both studied areas the assessed contents of As were scattered over a relatively larger area than the average. 
Am. J. Environ. Sci., 6 (1): 33-40, 2010

Table 1: As and Sb contents in soil and plant samples

\begin{tabular}{|c|c|c|c|}
\hline Parameter & Ferneziu area $\left(\mathrm{n}^{\mathrm{a}}=8\right)$ & Săsar district area $\left(\mathrm{n}^{\mathrm{a}}=10\right)$ & Dura area $\left(n^{\mathrm{a}}=5\right)$ \\
\hline As in soil $\left(\mathrm{mg} \mathrm{kg}^{-1}\right)$ & $53 / 2.4-255^{\mathrm{b}}$ & $102 / 5.5-295$ & $0.73 / 0.25-1.25$ \\
\hline As in plants $\left(\mathrm{mg} \mathrm{kg}^{-1}\right)$ & $0.99 / 0.22-5.33$ & $0.63 / 0.11-1.45$ & $0.36 / 0.29-0.43$ \\
\hline $\mathrm{Sb}$ in soil $\left(\mathrm{mg} \mathrm{kg}^{-1}\right)$ & $21 / 5.3-40.6$ & $6.0 / 0.9-18.4$ & under $\mathrm{DL}^{\mathrm{c}}(0.5)$ \\
\hline $\mathrm{Sb}$ in plants $\left(\mathrm{mg} \mathrm{kg}^{-11}\right)$ & $0.05 / 0.02-0.14$ & $0.03 / 0.02-0.08$ & under $\mathrm{DL}^{\mathrm{c}}(0.015)$ \\
\hline $\mathrm{pH}$ in soil (units of $\mathrm{pH}$ ) & $6.9 / 5.7-7.5$ & $6.0 / 4.5-7.2$ & $5.8 / 5.6-6.0$ \\
\hline
\end{tabular}

${ }^{\mathrm{a}}$ : Number of samples; ${ }^{\mathrm{b}}$ : Average/min-max value; ${ }^{\mathrm{c}}$ : DL detection limit

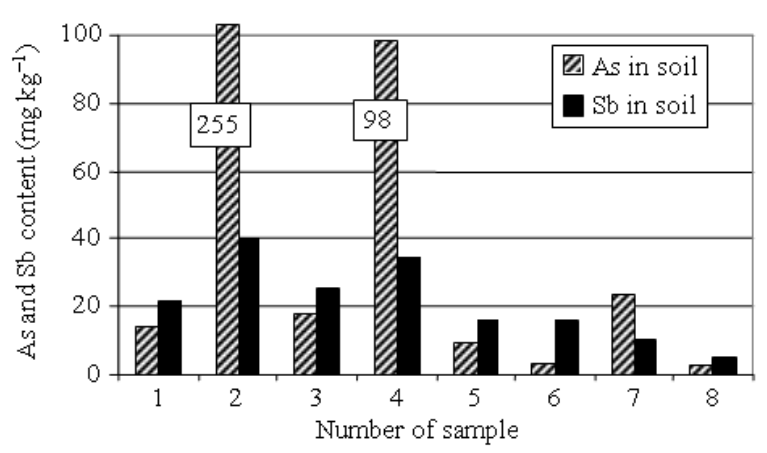

Fig. 2: As and $\mathrm{Sb}$ content in the soil samples from Ferneziu district

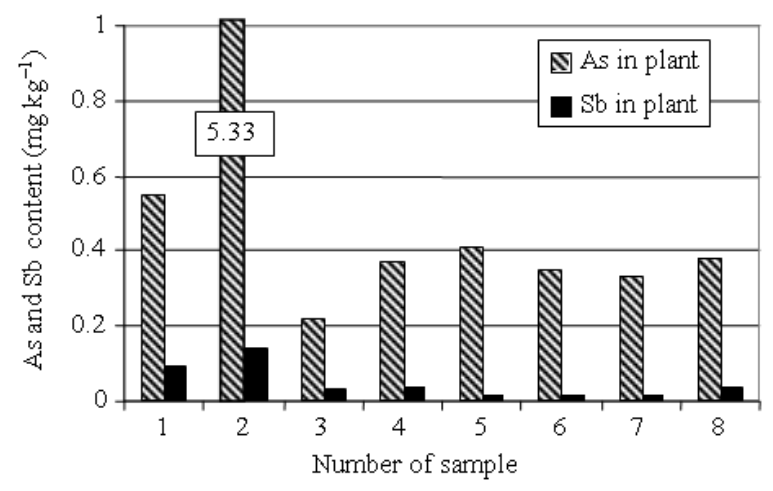

Fig. 3: As and $\mathrm{Sb}$ content in the plant samples from Ferneziu district

The As and $\mathrm{Sb}$ content in the soil and plants samples from the studied areas are represented in the graphs from Fig. 2 and 3 (Ferneziu district) and Fig. 4 and 5 (Săsar district).

As concerns $\mathrm{Sb}$ the situation was different, higher concentrations had been found in the Ferneziu district, near the metallurgical plant. The average content of $\mathrm{Sb}$ in Ferneziu district was $21 \mathrm{mg} \mathrm{kg}^{-1}$, while in the central and north-west residential area of the city (Săsar district) the average content of $\mathrm{Sb}$ was $5.5 \mathrm{mg} \mathrm{kg}^{-1}$; in comparison with the values admitted by the current legislation, in the Ferneziu district $88 \%$ of the samples had a content of $\mathrm{Sb}$ exceeding the alert threshold $\left(12.5 \mathrm{mg} \mathrm{kg}^{-1}\right)$ and $50 \%$ of the samples had a Sb content that was above the intervention alert $\left(20 \mathrm{mg} \mathrm{kg}^{-1}\right)$,
Table 2: Pearson's correlation coefficients (r) of As and $\mathrm{Sb}$ in soil and plants and $\mathrm{pH}$ of soil

\begin{tabular}{lllllr}
\hline & As-S $^{\mathrm{a}}$ & As- $^{\mathrm{b}}$ & $\mathrm{Sb}^{\mathrm{S}} \mathrm{S}^{\mathrm{c}}$ & $\mathrm{Sb}-\mathrm{P}^{\mathrm{d}}$ & \multicolumn{1}{c}{$\mathrm{pH}$} \\
\hline $\mathrm{As}-\mathrm{S}^{\mathrm{a}}$ & 1 & $0.523^{*}$ & $0.453^{*}$ & 0.368 & -0.158 \\
$\mathrm{As}-\mathrm{Pb}$ & & 1.000 & $0.509^{*}$ & $0.800^{*}, * *$ & -0.297 \\
$\mathrm{Sb}-\mathrm{Sc}$ & & & 1.000 & $0.538^{*}, * *$ & 0.429 \\
$\mathrm{Sb}-\mathrm{P}^{\mathrm{d}}$ & & & & 1.000 & -0.093 \\
$\mathrm{pH}$ & & & & & 1.000 \\
\hline
\end{tabular}

${ }^{\text {a }}$ : As in soil; ${ }^{\text {b: }}$ : As in plant; ${ }^{\text {c: }}$ Sb in soil; ${ }^{\text {d: }}$ Sb in plant; *: Significant on the level of probability 0.05 ; **: Significant on the level of probability 0.01

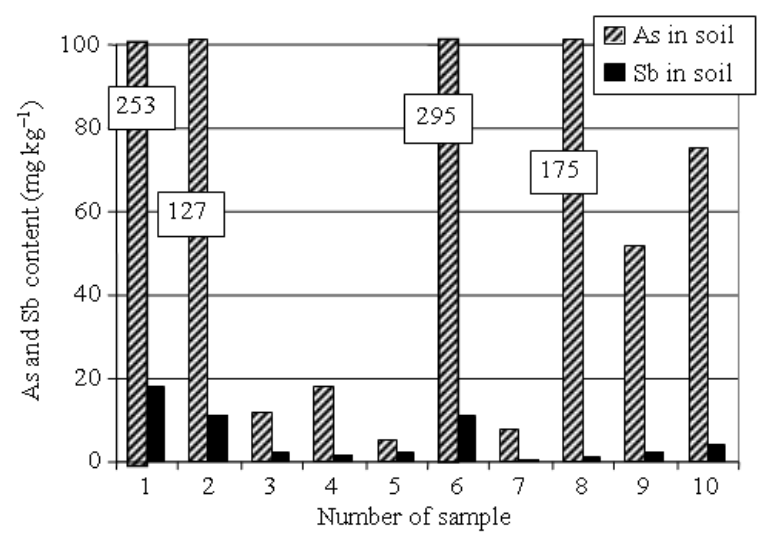

Fig. 4: As and Sb content in the soil from Săsar district

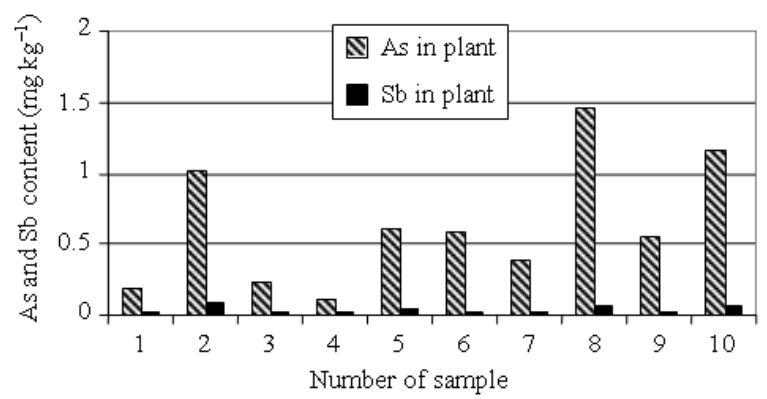

Fig. 5: As and $\mathrm{Sb}$ content in the plants from Săsar district

as to the Săsar district, $10 \%$ of the samples were above the alert threshold and the content of none of the samples exceeded the intervention threshold.

The domain of variation of the $\mathrm{Sb}$ contents was more limited in both studied areas in comparison with 
the variation domain of As. Generally, the Sb contents were 3-15 times lower than those of As, in the way in the earth crust the As:Sb ratio is 10:1.

The highest As content in plants were found in the samples from Ferneziu district, the average content being $0.99 \mathrm{mg} \mathrm{kg}^{-1}$, while $25 \%$ of the samples had a higher content than $0.5 \mathrm{mg} \mathrm{kg}^{-1}$, which is the limit admitted by the Romanian legislation for the content of As in the plants used as food products. In Săsar district, the average As content in plants was $0.63 \mathrm{mg} \mathrm{kg}^{-1}$ and $60 \%$ of the samples had a higher content than the admitted limit, while in the Dura reference zone, the average content of As in plants was $0.36 \mathrm{mg} \mathrm{kg}^{-1}$ and all the contents in plants were less than the admitted limit of $0.5 \mathrm{mg} \mathrm{kg}^{-1}$. The highest As concentration in plants recorded in Ferneziu district was 10.7 times higher and in the center of the city the content of As in plants was maximum 3 times higher than the admitted limit.

The highest content of Sb in plants had been found also in the samples from Ferneziu district, the average concentration being $0.05 \mathrm{mg} \mathrm{kg}^{-1}$. In Săsar district, the average content of $\mathrm{Sb}$ in plants was $0.03 \mathrm{mg} \mathrm{kg}^{-1}$ and in the Dura reference zone, the $\mathrm{Sb}$ content in the plant samples was below the quantification limit of the analysis method (i.e., less than $0.03 \mathrm{mg} \mathrm{kg}^{-1}$ ).

Table 1 presents also the $\mathrm{pH}$ values of the studied soil samples. The majority of the soil samples have an average of slightly acid $\mathrm{pH}$. The highest acidity is found in the samples from the reference zone and it diminishes as one comes closer to the polluting source. Around the metallurgical plant, the average $\mathrm{pH}$ of the soil samples was 6.9 (the variation domain between 5.7 and 7.5).

The low contents of $\mathrm{As}$ and $\mathrm{Sb}$ in plants in comparison with the much higher contents from the soil may suggest a potential inhibition of their transfer due to the other metals abundant in the soil in the zone $(\mathrm{Pb}, \mathrm{Cu}, \mathrm{Zn}, \mathrm{Cd})$. It has been demonstrated that the plants' absorption of $\mathrm{Zn}$ from the soil inhibits that of cadmium, but has no effect on the $\mathrm{Mn}$ and $\mathrm{Cu}$ absorption (Wu et al., 2003).

\section{DISCUSSION}

Taking into consideration the limited number of samples and locations under study, for the interpretation of the data we have used the boxplot type of diagram that offers information concerning the central tendency and form of the studied distribution. The boxplot diagram reflects graphically the summary through 5 values of the studied distribution: the minimum value, the first quartile Q1 (25\%), the median, the third quartile Q3 (75\%) and the maximum value. The graphic represents also the values situated outside the distribution (outliers). The values higher than Q3+1,5IQR and lower than Q1-1,5IQR are considered aberrant values/outliers. The IQR interval is the one between Q3 and Q1 and is graphically represented by a rectangle (box). Inside it is the median graphically represented by a horizontal line. The intervals (Xmin, Q1) and (Q3, Xmax) are represented each by a line (,moustache") as an extension of the rectangle. The aberrant values are represented by void circles.

Figure 6 and 7 represent the boxplot diagrams for As and respectively $\mathrm{Sb}$ in Soil (S) and Plant (P) samples from the studied areas. The representation of boxplot diagrams in Fig. 6 and 7 shows a homogeneity of the As and $\mathrm{Sb}$ contents in plants in all the studied areas, while the soil contents vary in a wide range of limits, except the Dura reference area.

The Pearson's correlation analysis as shown in Table 2 (Pearson $\mathrm{r}$ coefficient) between $\mathrm{As}$ and $\mathrm{Sb}$ content in soil and plants as well as $\mathrm{pH}$ of the soil had been also made, using the statistical instruments offered by Windows Excel. A strong positive correlation between $\mathrm{As}$ and $\mathrm{Sb}$ contents in plants was noticed. A significant correlation both for the probability levels $p<0.05$ and $p<0.01$ was observed between the Sb content in the soil and in the plants.

In the same way, for a level of probability $p<0.05$, we can notice a positive correlation between As contents in soil and in plants, as well as for the As and $\mathrm{Sb}$ contents in the soil. No correlation has been obtained for the As and $\mathrm{Sb}$ content in the soil and respectively in the plants with the $\mathrm{pH}$ of the soil.

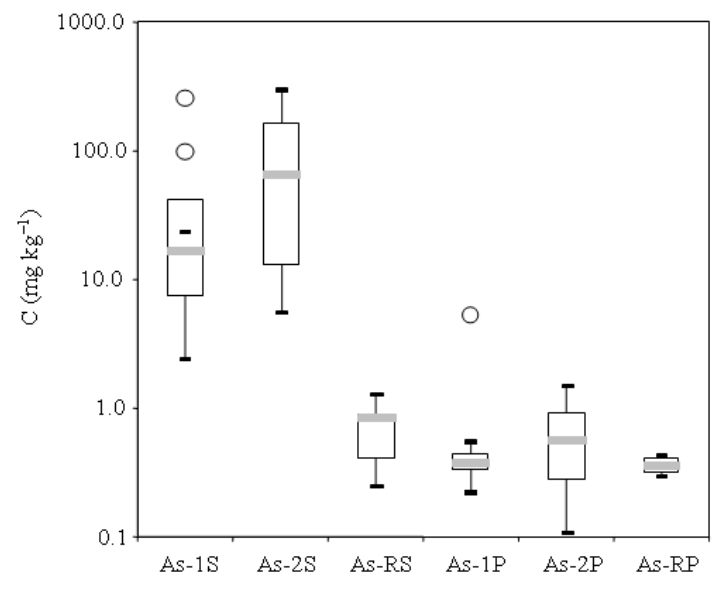

Fig. 6: Boxplot diagram for As in Soil (S) and Plant (P) samples in the studied zones; (1) Ferneziu district; (2) Săsar district; ® Dura reference area 
Am. J. Environ. Sci., 6 (1): 33-40, 2010

Table 3: Comparison of As and Sb content in soil and plants found in Baia Mare area with other studies

\begin{tabular}{|c|c|c|c|c|}
\hline \multirow[b]{2}{*}{ Location of the studied area } & \multicolumn{2}{|c|}{ As $\left(\mathrm{mg} \mathrm{kg}^{-1}\right)$} & \multicolumn{2}{|l|}{$\mathrm{Sb}\left(\mathrm{mg} \mathrm{kg}^{-1}\right)$} \\
\hline & In soil & In plants & In soil & In plants \\
\hline Germany (mining site) (Hammel et al., 2000) & & & Max 500 & $0.09-2.2$ \\
\hline Poland (metallurgical site) (Gal et al., 2006) & $3.13-9.16$ & & & \\
\hline Spain (mining site) (Casado et al., 2007) & $42-4530$ & $0.02-2.77$ & $60-230$ & $0.002-4.25$ \\
\hline Scotland (mining site) (Gal et al., 2006) & $17.4-50$ & & $1.19-10$ & \\
\hline Italy (mining site) (Gal et al., 2006) & $16-691$ & & $1.63-11.44$ & \\
\hline Bulgaria (reference soil) (Kabata-Pendias and Pendias, 2001) & & & $1.25-2.32$ & \\
\hline England (reference soil) (Kabata-Pendias and Pendias, 2001) & & & $0.29-1.3$ & \\
\hline Norway (reference soil) (Kabata-Pendias and Pendias, 2001) & & & $0.17-2.2$ & \\
\hline China (metallurgical site) $(\mathrm{He}, 2007)$ & & & $100.6-5045$ & \\
\hline Australia (mining site) (Sultan, 2007) & 7.44-395.8 & & & \\
\hline New Jersey (chemical pesticides with As) (Cheng et al., 2007) & $3.8-387$ & & & \\
\hline New Jersey (reference soil) (Cheng et al., 2007) & $1.6-4.6$ & & & \\
\hline Canada (reference soil) (Kabata-Pendias and Pendias, 2001) & & & $0.05-2.0$ & \\
\hline Brasilia (in park) (Figueiredo et al., 2007) & $11.5-21.5$ & & $1.4-2.5$ & \\
\hline Mexico (mining site) (Rosas et al., 1999) & $\operatorname{Max} 30$ & $0.24-3.06$ & & \\
\hline Romania, Present study (mining and metallurgical site) & $2.4-295$ & $0.11-5.33$ & $0.85-40.6$ & $<0.03-0.14$ \\
\hline Romania, Present study (reference soil) & $0.25-1.25$ & $0.29-0.43$ & $<0.5$ & $<0.03$ \\
\hline
\end{tabular}

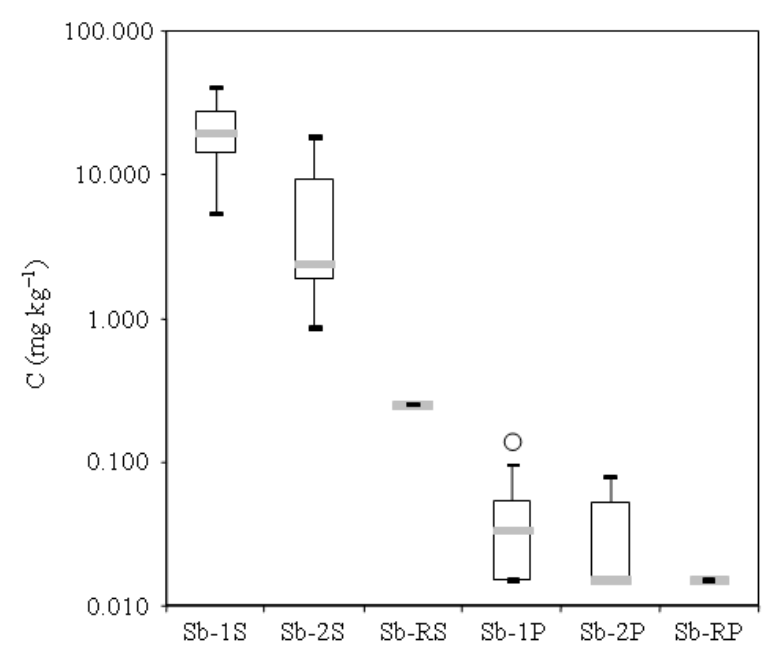

Fig. 7: Boxplot diagram for $\mathrm{Sb}$ in the Soil (S) and Plant (P) samples from the studied areas; (1) Ferneziu district; (2) Săsar district; (R) Dura Reference area

The results show the existence of a correlation between the As and $\mathrm{Sb}$ contents in the soil and respectively in the plants, taking us to the presumption that these elements follow a common cycle between the polluting source, soil and plant. It is generally accepted that in the process of the absorption of metals from the soil by plants the dominant factor is the metal content from the soil, but in the same time it can be affected by other factors as well including the $\mathrm{pH}$ of the soil (Jung and Thorntorn, 1996).
In this context it is of interest that there is no correlation between the studied content of microelements from the soil and plants and the $\mathrm{pH}$ of the soil, although recent studies have concluded that the $\mathrm{pH}$ can be the most important factor that determines the metal absorption by the plants from the soil (Kirkham, 2006; Jung, 2008). But the soluble forms of Sb, especially $\mathrm{Sb}(\mathrm{V})$ are absorbed from the surface of minerals and the process of adsorption is favored by the acidic $\mathrm{pH}$ and the oxidizing conditions (Casado et al., 2007).

Through the regression analysis a significant statistical correlation has been obtained $(\mathrm{p}<0.05)$ only between the $\mathrm{As}$ and $\mathrm{Sb}$ contents in plants (the construction of the regression line, $y=0.0465 x+0.0052$ cu $\mathrm{R}^{2}=0.5942$ ), according to the graphic representation from Fig. 8. Other research studies have shown also poor correlations between the total content of elements from the soil and their content in the plants, the absorption from the soil being more plausibly controlled by the soil solution composition (Chojnacka et al., 2005).

Comparing the results obtained in this study for the As and $\mathrm{Sb}$ content in the soil and in the plants, in the areas with anthropogenic impact and the reference areas, one can notice that these follow the same tendencies as in other countries in Europe or the rest of the world, taking into consideration for each area the specificity of the impact of the predominant anthropogenic activities. The comparative data is represented in Table 3. 


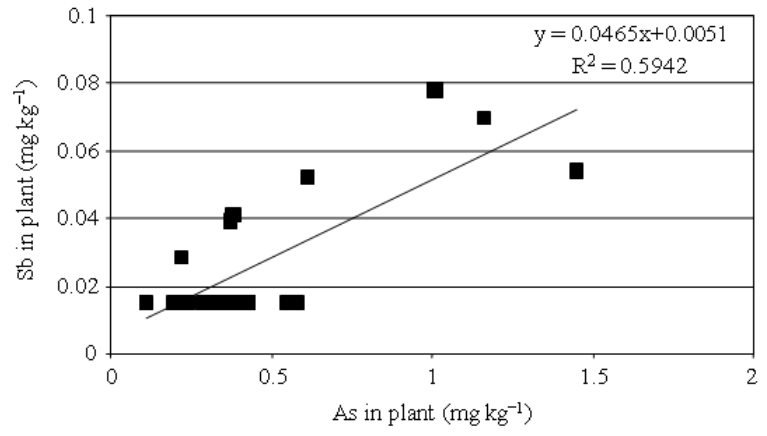

Fig. 8: The relation between $\mathrm{As}$ and $\mathrm{Sb}$ in the plant samples from the studied areas

\section{CONCLUSION}

The study presents original results on the soil pollution in Baia Mare area as regard to the As and Sb contents in soil and plants. It should be highlighted that no results concerning the content of $\mathrm{Sb}$ in soil and plants in Baia Mare area have been previously reported in scientific papers.

Hence, the following conclusions can be drawn up:

The average content of As in the soil of Baia Mare area (Ferneziu and Săsar districts) exceeded the intervention threshold $\left(25 \mathrm{mg} \mathrm{kg}^{-1}\right)$, while the average content of $\mathrm{Sb}$ in the soil exceeded the intervention threshold (20 $\mathrm{mg} \mathrm{kg}^{-1}$ ) only in the Ferneziu district. Generally, the Sb contents were 3-15 times lower than those of As.

Most of the soil samples have slightly acidic $\mathrm{pH}$. The highest acidity is found in the samples from the reference zone and it diminishes as one comes closer to the polluting source.

The highest As concentration in plants recorded in the Ferneziu district was 10.7 times higher than the admitted limit and in the center of the city (Săsar district) the content of As in plants was maximum 3 times higher.

The Boxplot diagrams show the homogeneity of the As and Sb contents in plants in all the studied areas, while the soil contents vary in a wide range of limits, except the Dura reference are.

The Pearson's correlation analysis shows the correlation between the As and Sb contents in the soil and respectively in the plants. Hence we can presume that these elements follow a common cycle between the polluting source, soil and plant.

A significant statistical correlation has been obtained $(\mathrm{p}<0.05)$ only for the As and $\mathrm{Sb}$ contents in plants through the analysis of regression.

Comparing the results obtained in this study for the $\mathrm{As}$ and $\mathrm{Sb}$ content in soil and plants in the areas with anthropogenic impact and the reference areas, one can observe that these follow the same trends as in other countries in Europe or worldwide.

The results of the present study reveal the low bioavailability of $\mathrm{Sb}$ and $\mathrm{As}$ in the soil within the studied areas and the importance of establishing the transfer coefficients from soil to plant for these elements as a real indicator for the soil pollution level.

\section{ACKNOWLEDGEMENT}

The present researches were supported by the Romanian Ministry of Education and Research, within the PNCDI II Program (Project CISPPA no. 52157/2008).

\section{REFERENCES}

Casado, M., H.M. Anawar, A. Garcia-Sanchez and I. Santa Regina, 2007. Antimony and arsenic uptake by plants in an abandoned mining area. Commun. Soil Sci. Plant Anal., 38: 1255-1275. DOI: 10.1080/00103620701328412

Cheng, Z., B.M. Buckley, B. Katz, W. Wright and R. Bailey et al., 2007. Arsenic in tree rings at a highly contaminated site. Sci. Total Environ., 376: 324-334. DOI: 10.1016/j.scitotenv.2007.01.074

Chojnacka, K., A. Chojnacki, H. Gorecka and H. Gorecki, 2005. Bioavailability of heavy metals from polluted soils to plants. Sci. Total Environ., 337: 175-182. DOI: 10.1016/j.scitotenv.2004.06.009

Cordos, E.A., T. Frentiu, M. Ponta, I. Marginean, B. Abraham and C. Roman, 2006. Distribution study of inorganic arsenic (III) and (V) species in soil and their mobility in the area of Baia-Mare, Romania. Chem. Speciat. Bioavailab., 18: 11-25. DOI: 10.3184/095422906782146294

Cordos, E.A., C. Roman, M. Ponta, T. Frentiu and R. Rautiu, 2007. Evaluation of soil pollution with copper, lead, zinc and cadmium in the mining area Baia Mare. Rev. Chim. (Bucharest), 58: 470-474. http://www.revistadechimie.ro/pdf/5_2007_9.pdf

Damian, F., G. Damian, R. Lacatusu, G. Macovei and G. Iepure et al., 2008. Soils from the Baia Mare zone and the heavy metals pollution. Carpth J. Earth Environ. Sci., 3: 85-98. http://www.ubm.ro/sites/CJEES/upload/SOILS_FR OM_THE_BAIA_MARE_ZONE.pdf

De Gregori, I., E. Funetes, D. Olivares and H. Pinochet, 2004. Extractable copper, arsenic and antimony by EDTA solution from agricultural soils. J. Environ. Monit., 6: 38-47. DOI: 10.1039/b304840c 
Figueiredo, A.M.G., S.P. Camargo, A.C. Pavese, F.C. Gumiero, J. Enzweiler and J.B. Sígolo, 2007. Metal assessment in urban park soils in são paulo. 1. Ibirapuera Park. Proceeding of the International Nuclear Atlantic Conference-INAC, Sept. 30-Oct. 5, Associação Brasileira De Energia Nuclear, Santos, SP, Brazil, $\quad$ pp: 1-6. http://pintassilgo2.ipen.br/biblioteca/2007/inac/121 43.pdf

Frentiu, T., M, Ponta, E. Levei, E. Gheorghiu, I. Kasler and E.A.Cordos, 2008. Validation of the tessier scheme for speciation of metals in soil using the Bland and Altman test. Chem. Paper, 62: 114-122. DOI: 10.2478/s11696-007-0087-3

Frentiu, T., M. Ponta, E. Levei and E.A. Cordos, 2009. Study of partitioning and dynamics of metals in contaminated soil using modified four-step BCR sequential extraction procedure. Chem. Paper, 63: 239-248. DOI: 10.2478/s11696-008-0102-3

Gal, J., A.S. Hursthouse and S.J. Cuthbert, 2006. Chemical availability of arsenic and antimony in industrial soils. Environ. Chem. Lett., 3: 149-153. DOI: $10.1007 / \mathrm{s} 10311-005-0022-1$

Grancea, L., L. Bailly, J. Leroy, D. Banks and E. Marcoux et al., 2002. Fluid evolution in the Baia Mare epithermal gold/polymetallic district, Inner Carpathians, Romania. Mineralium Deposita, 37: 630-647. DOI: 10.1007/s00126-002-0276-5

Hammel, W., R. Debus and L. Steubing, 2000. Mobility of antimony in soil and its availability to plants. Chemosphere, 41: 1791-1798. DOI: 10.1016/S0045-6535(00)00037-0

He, M., 2007. Distribution and phytoavailability of antimony at an antimony mining and smelting area, Hunan, China. Environ. Geochem. Health, 29: 209219. DOI: $10.1007 / \mathrm{s} 10653-006-9066-9$

Jung, M.C. and I. Thorntorn, 1996. Heavy metal contamination of soils and plants in the vicinity of a lead-zinc mine, Korea. Applied Geochem., 11: 53-59. DOI: 10.1016/0883-2927(95)00075-5

Jung, M.C., 2008. Heavy metal concentrations in soils and factors affecting metal uptake by plants in the vicinity of a korean $\mathrm{Cu}-\mathrm{W}$ mines. Sensors, 8: 2413-2423. DOI: $10.3390 / \mathrm{s} 8042413$
Kabata-Pendias, A. and H. Pendias, 2001. Trace Elements in Soils and Plants. 3rd Edn., CRC Press, Boca Raton, USA., ISBN: 0-8493-1575-1, pp: 413.

Kirkham, M.B., 2006. Cadmium in plants on polluted soils. Geoderma, 137: 19-32. DOI: 10.1016/j.geoderma.2006.08.024

Mandal, B.K. and K.T. Suzuki, 2002. Arsenic round the world: A review. Talanta, 58: 201-235. DOI: 10.1016/S0039-9140(02)00268-0

Miclean, M., E. Levei, M. Senila, B. Abraham, C. Roman and E. Cordos, 2008. Heavy metal contamination of soil in Baia Mare mining area. Stud. Chem., 53: $57-63$.

Nakamaru, Y., K. Tagami and S. Uchida, 2006. Antimony mobility in Japanese agricultural soils. Environ. Pollut., 141: 321-326. DOI: 10.1016/j.envpol.2005.08.040

Rosas, I., R. Belmont, A. Armient and A. Baez, 1999. Arsenic Concentrations in Water, Soil, Milk and Forage in Comarca Lagunera, Mexico. Water Air Soil Pollut., 112: 133-149. DOI: 10.1023/A:1005095900193

Sultan, K., 2007. Distribution of metals and arsenic in soils of central Victoria (Creswick-Ballarat), Australia. Arch. Environ. Contam. Toxicol., 52: 339-346. DOI: 10.1007/s00244-006-0050-2

Tighe, M., P. Ashley, S. Lockwood and S. Wilson, 2005. Soil, water and pasture enrichment of antimony and arsenic within a coastal floodplain system. Sci. Total Environ., 347: 175-186. DOI: 10.1016/j.scitotenv.2004.12.008

$\mathrm{Wu}$, F., G. Zhang and J. Yu, 2003. Interaction of cadmium and four microelements for uptake and translocation in different barley genotypes. Commun. Soil Sci. Plant Anal., 34: 2003-2020. DOI: 10.1081/CSS-120023233 